\title{
Bureaucracy and student performance in US public schools
}

\author{
MICHAEL L. MARLOW \\ Department of Economics, California Polytechnic State University, San Luis Obispo, \\ CA 93407, USA \\ E-mail:mmarlow@calpoly.edu
}

This paper tests the hypothesis that monopoly power of school districts allows bureaucratic expansion and fosters poor academic performance in the public school system in California. Evidence indicates that monopoly power is positively associated with employment of administrators and teachers, and therefore supports the bureaucratic expansion hypothesis. While numbers of teachers do not influence performance measures, numbers of administrators are shown to positively affect performance - results that suggest that too many teachers, but too few administrators, are employed. While bureaucracy theory may explain the resource misallocation, other reasons might include rising public pressures on hiring teachers over administrators, spending equalization policies, and the weak California economy in the period under investigation.

\section{INTRODUCTION}

It is commonplace to blame poor education performance on lack of teachers or funding, but it is uncommon to blame poor performance on lack of administrators. A growing public perception is that US public schools are increasingly burdened by bureaucracies that stifle creativity of teachers through standardization and control of their activities. Over-expanded bureaucracies are also believed to crowdout funding that might be better allocated to teachers, equipment and other inputs in the production of education. Despite appearances of growing support for this view, little empirical evidence is available with which to assess whether or not school bureaucracies have over-expanded. This paper examines what role school bureaucracies play in the performance of the public school system of California, where student performance or achievement is measured by SAT (School Achievement Test) scores and dropout rates.

That performance is inversely related to bureaucratic size within an over-expanded public school system is one hypothesis. A counter-hypothesis is that bureaucracies are too small and therefore their expansion would raise performance. This could arise in various ways. If, for instance, substantial public pressures to minimize numbers of administrators and shift resources to other endogenous inputs such as teachers and other staff are present, resources could be misallocated in the sense that too many other resources are employed relative to administrators. California has recently implemented class-size reduction policies that, in effect, shift resources toward teachers and away from other resources. While such reallocation may raise performance, it is important to recognize that public policy changes are not private market-driven as would occur when profit-maximizing firms reallocate resources due to competitive pressures. Rather, public policies are chosen within public or political markets, and, as the public perceives that there are too many administrators, pressures arise to reallocate resources away from administrators and towards other inputs. Whether reallocation improves performance by allocating resources more efficiently is an empirical issue.

Resource misallocation might also arise when school districts or states experience significant changes in school populations, state budgets, or adverse economic environments. California has experienced a dramatic rise in student population - over 1.2 million since 1983-1984, which represents more students than currently served by 42 other states. ${ }^{1}$ Moreover, during much of the 1990 s

\footnotetext{
${ }^{1}$ Unless otherwise stated, data in this section is from California Department of Education and the California Legislative Analyst's Office.
} 
California lagged behind most other states in output growth which has significantly reduced revenues for state and local governments. These factors appear to have significantly impacted the public school system. While spending-per-student was roughly at the US average in 1976, California averaged US\$4724 per student in 1994 1995, which was US\$1170 less than the national average of US\$5894 and contributed to a national ranking of $42 .^{2}$ Even under strong economic conditions it is debatable that resources are efficiently allocated in public markets, but it becomes more doubtful during times of economic distress. Although conditions may be temporary, the possibility remains that bureaucratic resources are too scarce and their expansion would raise performance, even though public pressure may result in further contraction.

These hypotheses are examined on a data set that includes all school districts in California over 1992 and 1993. The focus on California provides a rich and large data set to examine the role that bureaucracy plays on academic performance. The public school system (primary and secondary) is the nation's largest with 1002 school districts, employing over 410000 employees, with over 11000 administrators, and servicing over 5.3 million pupils. Funding in 1996-1997 was $\$ 32$ billion. Over 12\% of children in kindergarten through grade 12 reside in California, or one of eight US students in 1994-1995. The focus on California also provides for an empirical examination within a common set of funding constraints. California's Proposition 98 of 1988 guarantees a minimum level of state support for all schools and is an important determinant of school spending levels. As each state has its own budgetary institutions and mandates, cross-state examination may incorrectly conclude that variation in academic performance or resource employment is caused by bureaucracy when that variation results from differences in budgetary institutions. Most states also attempt to equalize across school districts on the basis of income and past performance, but do so with different intensity, and therefore equalization efforts are also potentially important factors that explain cross-state variation in performance. This paper avoids these problems by empirically testing hypotheses using data only on California and therefore eliminates cross-state differences in budgetary institutions and equalization efforts that would otherwise influence relationships between bureaucracy and performance of public school systems.

\section{BUREAUCRACY MODEL AND PERFORMANCE IN PUBLIC EDUCATION MARKETS}

Bureaucrats, or administrators, are both substitutes of and complements for other inputs in the production of educa- tion. In their managerial role they allocate resources and, to some degree, assume risk that efforts do not meet performance standards placed on them by elected politicians and/or voters and parents. They are complements since their productivity is linked with employment of other inputs such as teachers, staff, and classrooms. Administrators have substitutes since other employees may also take on the managerial roles of decision-making on various activities such as teaching methods and overall policy-making. Administrators provide a vital function in the production of education but, as with any scarce resource, may be overused or underused relative to other resources.

Optimality conditions for the efficient allocation of administrators follow from conventional production theory that models production as a function of marginal products of inputs, input costs, and budgets. Optimal allocations arise when marginal product-to-resource price ratios are equal across inputs as developed in the standard isoquant and iso-budget model of microeconomics. Inputs are administrators, teachers, other staff, buildings, land and other endogenous inputs that produce education. Optimal levels of inputs for a given education budget arise when reallocation that raises production without costing more is impossible.

Some inputs such as parentage and socioeconomic characteristics are exogenous in the sense that public schools cannot pick-and-choose students. However, these inputs are important because they may affect productivity of endogenous inputs such as teachers or administrators. For instance, heterogeneous student bodies cause marginal products of teachers and administrators to vary by school. Similarly, input prices, as well as budgets, vary across locations thus causing variation in optimal input ratios. Optimal resource allocation will therefore vary across locations and suggests that simple observation of variation in student-teacher or administrator-teacher ratios across schools do not necessarily indicate varying degrees of efficiency.

\section{Education in a monopolistic market}

The growing literature on government monopoly suggests that public school systems are characterized by a high degree of monopoly power. Private competitive markets are generally believed to allocate resources efficiently, but Niskanen's (1971) theory of bureaucracy predicts that resources are not efficiently allocated in public markets that lack competition and control by sponsors such as elected officials or parents in the case of education. Bureaucracy theory predicts that, because profit maximization is not a goal of bureaus, other rewards are pursued. In public education, rewards may include maximization of

\footnotetext{
${ }^{2}$ California's Rankings, 1994-1995, ED FACT Sheet, Education Data Partnership, February 1996.
} 
budgets, salaries and employees, as well as pursuit of amenities such as vacation time, plush offices and attractive classrooms. Academic performance is another possible pursuit, but this direction would only be emphasized in competitive settings and/or when administrators are effectively constrained by sponsors (parents or politicians) that prefer this direction. At issue is the extent to which monopoly conditions allow administrators to pursue goals that favour their interests over interests of those who want a public school system that efficiently delivers high performance.

Within a public exchange model whereby voters/parents and policymakers determine education policies, voters/ parents communicate via voice and exit options to school administrators. ${ }^{3}$ Voice options include voting and expressing views directly to administrators and exit options indicate the extent to which dissatisfied parents may move their children from one school to another as they search for preferred education programmes. Exiting is a last resort, as developed in Charles Tiebout's (1956) model of 'votingwith-your-feet', and exercised when parents conclude they cannot effectively influence local policies through voice options. The Leviathan model of Brennan and Buchanan (1980) argues that credible threats of exit are an effective means of maintaining or improving programme quality because policymakers are better able to pursue selfinterests when few exit doors are available. With relatively few competitors, the Leviathan model predicts that administrators are able to pursue policies reflecting their narrow interests such as bureaucratic over-expansion, as opposed to simply pursuing parental interests of high quality education.

Public school systems in California offer limited exit options. It might appear that choices are plentiful with over 7700 public schools in over 1000 school districts and 57 counties, but parents are routinely assigned particular schools within their districts. ${ }^{4}$ These 'exclusive territories' spawn local monopolies whereby parents must undertake costly relocation if they send children to better schools, even though moves may be just a short distance. Exclusive territory arrangements limit exit options and, according to the Leviathan model, allow academic performance to suffer as administrators are freer to pursue self-interests.

Financing of public education also discourages competition from private schools since individual tax assignments are mostly unrelated to whether one has school-age chil- dren or to numbers of children. ${ }^{5}$ This is simply a consequence of the ability-to-pay principal of taxation whereby tax bills are not assigned on the basis of benefits received, as well as attempts to tax third-party beneficiaries of public education. Primary recipients of public education are therefore essentially charged zero unit prices and stands in direct contrast to private education where unit prices reflect nonzero marginal (private) costs. Private education carries a unit price that far exceeds the zero unit price of public education and, as a result, public education dominates provision of education as this price advantage keeps the private education market relatively small and perhaps not a particularly strong competitive threat to public education. Until school vouchers or other policies significantly break the price advantage, the public market will undoubtedly continue to dominate the education market. ${ }^{6}$ Currently, the public market controls over $90 \%$ of the market at the primary and secondary level in the USA, as measured by dollars spent on education.

A small private market in education indicates lack of competition and may suggest significant monitoring problems for parents/taxpayers who are interested in high academic performance. Niskanen (1971) argues that monopoly conditions allow public employees to operate at relatively high levels of autonomy from sponsors when there are high monitoring costs and lack of private market counterparts with which to make comparisons of such items as costs and performance. Since relatively few school personnel are elected, and given the autonomy that tenure offers many teachers, sponsors are likely to find oversight a relatively difficult endeavour, especially when there are limited private market counterparts with which to make comparisons. Indeed, such conditions may make it extremely difficult for sponsors to effectively assess whether arguments for higher funding made by school administrators and teachers' unions stem from self-interested attempts to over-expand or genuine attempts to improve educational performance in least-cost manners.

California's system of shared taxation may also encourage monopoly power in the public school system. ${ }^{7}$ Local school districts used to be mostly funded by local revenues, but for the last 25 years funding has been dominated by decisions made in the state capital of Sacramento. Propositions 13 and 98, with the latter passed in 1988, mandate minimum funding guarantees for kindergarten through community colleges. Proposition 98 constraints now account for roughly $80 \%$ of total funding. Perhaps

\footnotetext{
${ }^{3}$ These options were introduced in Hirschman (1970) and are discussed in the context of government in Marlow (1992) and, within a model of public education, in Marlow (1997).

${ }_{5}^{4}$ See West (1990).

${ }_{6}^{5}$ Tax bills even tend to be lower for parents when tax deductions and credits are awarded on the basis of numbers of school-age children.

${ }^{6}$ A rapidly expanding literature focuses on private schools. Research includes Sonstelie (1979), Martinez-Vazquez and Seaman (1985),

West and Palsson (1988), Hamilton and Macauley (1991), Couch et al. (1993), and Newmark (1995).

${ }^{7}$ See California Legislative Analyst's Office, January 1995 for a discussion of school finance.
} 
the most important constraint is imposed by the Serrano v. Priest ruling of 1972 in which the Supreme Court of California mandated restructuring of the school finance system to virtually eliminate spending differences between school districts on the basis of wealth. In effect, court rulings mandated that finance be tied to a system of shared taxation whereby the state government was responsible for collecting taxes from local governments and then returning revenues to school districts on the basis of factors such as numbers of students and redistribution in the direction of poorer districts. This funding system limits abilities of local officials to make local funding decisions and constrains the ability of school districts to compete with one another on the basis of how well they use local funds to deliver quality school programmes.

Some school districts - especially wealthy ones - did not like the system of shared taxation. Fischel (1989) argues that Proposition 13 was caused by Serrano since it allowed high property value school districts/counties to bypass some of the redistribution required by Serrano. Proposition 13 capped property tax rates and growth in assessed value, reducing by $54 \%$ the amount of property taxes available to fund services provided by cities, counties, school districts, and other agencies. ${ }^{8}$ Silva and Sonstelie (1995) find that Serrano created some equalization across school districts, but also contributed to a statewide decline in average funding per student. The US General Accounting Office (1997) concludes that California needs to shift $35 \%$ more state funds from wealthy to poor or middle-income districts in order to meet equalization criteria, with current imbalances resulting from wealthier districts raising supplemental fees and parental contributions as well as political forces in the redistribution process.

California's shared taxation system contributes to school district monopoly power to the extent that it reduces exit options of parents who are dissatisfied with funding decisions of local school administrators. In effect, shared taxation protects and increases monopoly positions of school districts since it restricts inter-district competition on the basis of taxation, thus effectively creating one large monopoly government from which parents cannot easily escape, and according to the Leviathan view, to poor performance of public schools.

\section{Implications of monopoly view}

An implication of the monopoly view is that school administrators have an interest in over-expanding that exceeds their interest in improving educational performance. As discussed above, over-expansion may take place in any of the endogenous inputs of the education production function, but it is increasingly common to predict overexpansion in the hiring and associated funding of administrative positions. A testable hypothesis is then that the greater is monopoly power of public school systems, the greater is administrative over-expansion which leads to lower academic performance.

Anderson et al. (1991) take the monopoly model a step further with the prediction that administrators prefer to over-expand by hiring additional non-teachers over teachers because the latter enjoy higher autonomy and are therefore more difficult for administrators to control. Expansion of secretaries and clerks are also hypothesized to provide non-pecuniary income to administrators in the form of services. Non-teachers are also less organized than teachers which creates less trouble for administrators because unions attempt to mandate work rules and hiring practices that favour teachers. Finally, because teachers are often tenurable, they enjoy relatively high autonomy from administrators. Empirical investigation of cross-state variations in 1984 reveal support for their predictions since states with relatively large educational bureaucracies tend to perform relatively poorly on standardized tests and also tend to have relatively high dropout rates. They also find that greater employment of non-teachers and aides exert negative effects on performance, but teachers exert positive effects on performance.

However, it should be noted that non-optimal allocations of educational inputs do not necessarily indicate presence of an inverse relation between administrative resources and performance. As Brewer (1996) discusses, too many administrators may be reflected in diverse ways. In an extreme version, an inverse relation between administrative resources and performance exists, as when their employment is characterized by marginal products below zero, and therefore, simple scaling-back of administrators raises total product or performance. Under this version, a negative coefficient on administrative employment would be found in a regression explaining performance. A weaker version has administrators not exerting direct negative effects on total performance, but nonetheless they are less productive than other inputs such as teachers. Shifting a dollar at the margin from administrators to teachers raises performance, but note that this weaker version of unproductive administration does not indicate an inverse relationship between administrators and performance since marginal products are positive. But, the positive marginal influence of another dollar spent on teachers or other inputs exceeds that of administrators under this weaker version as would be evidenced by differences in estimated coefficients (divided by their salaries) in regression equations. Brewer (1996) finds little

\footnotetext{
${ }^{8}$ In a study of public schools in California, Downes (1996) finds evidence that school districts had monopoly power before and after Proposition 13, though somewhat less so after Proposition 13. Evidence of bureaucratic behaviour was that administrators substituted improved student performance for greater numbers of administrative staff.
} 
consistent evidence of statistically significant effects of school administration on educational performance in his study of 700 New York school districts over 1978-1987. ${ }^{9}$

\section{OTHER REASONS FOR INEFFICIENCY}

While it may be true that inefficient allocation of administrators causes poor performance, not all inefficient allocations are necessarily a product of bureaucratic monopoly power. There are various reasons apart from self-serving behaviour for why administrators may be poorly allocated in public school systems. One possibility stems from equalization policies that attempt to distribute funding equally across locations, but are not tied to optimal resource allocation. For instance, equalization will not tend to promote more teachers-assistants in area A simply because they are relatively cheap or more productive and discourage hiring of teachers-assistants in area B simply because they are relatively more expensive and less productive. Although such allocations would be efficient, it is questionable that equalization mandates focus on providing more efficient resource allocations. It is more likely that equalization efforts focus on providing funding that creates uniformity in teacher-student ratios and other parameters that are believed to be strongly linked to academic performance. However, as previously argued, with differences in input prices and marginal products there is no reason to suspect that uniformity in teacher-student ratios would reflect optimal allocations across schools. Moreover, there appears to be little evidence that such input ratios are systematically linked to student performance. ${ }^{10}$ This discussion suggests that equalization efforts may mandate inefficient input combinations and therefore contribute to poorer academic performance. Mandates may create too few or too many administrators and in this way exert an independent effect on allocation of administrators (as well as other inputs) that influences the relationship between administrators and academic performance and is apart from how equalization may create monopoly power that administrators exploit by over-expanding their domain.

Public pressures to limit administrators, but expand teachers or other inputs, may cause inefficient resource allocation as well. In 1996, California approved a classsize reduction initiative that in effect raises the hiring priority of teachers. If such policies are inconsistent with improved resource allocation, then another reason for inefficiency arises that is unrelated to monopoly powers of school bureaucracies. Note that these policies may cause a positive empirical relation between administrators (or other inputs) and performance when schools that are not subject to such pressures allocate efficient levels of administrators that exceed areas under pressure to hire too few administrators. This scenario suggests that greater numbers of administrators are positively related to performance and therefore provides a counter-hypothesi s to the extreme version that predicts a negative relationship between administrators and performance.

Finally, because resource reallocations arise in response to many factors such as changes in input prices, productivity (technology), budgets, as well as public perceptions and laws, changes take time to fully occur. Reallocations may be especially transitory during times of significant economic distress of the order that California experienced in the early to mid-1990s. Although temporary, resource allocations in any particular year are not necessarily efficient, and therefore we must be careful not to conclude that examination of one or more year's of data necessarily indicates steady-state equilibrium relationships between administrators and performance. California appears to be playing 'catch-up' with students-teacher ratios and other input-related parameters and therefore this examination of the 1992-1993 relationships are not necessarily long-term relationships nor are they necessarily indicative of relationships in other states.

\section{EMPLOYEE AND PERFORMANCE EQUATIONS}

Relationships between employees and performance are examined using counties in California as the unit of observation. The basic hypothesis is that monopoly power expands hiring beyond efficient levels, which then influences performance of public schools. This paper focuses on employees as the vehicle for bureaucratic over-expansion and separately considers three types of employees: administrators, teachers, and non-teachers. The following models of cross-county school employment and performance are estimated:

$$
\begin{gathered}
E M P L O Y E E_{i}=f\left(\text { HERF }_{i}, \text { DISTRICTS }_{i}, \text { DENSITY }_{i}\right) \\
\text { PERF }_{i}=f\left(E_{\text {MPLOYEE }}, \text { HERF }_{i}, \text { DENSITY }_{i}, \text { TAKER }_{i},\right. \\
\left.E_{\text {EDUCATION }}\right) .
\end{gathered}
$$

where EMPLOYEE $E_{i}=$ administrators, or teachers, or non-teachers, per primary and secondary student,

\footnotetext{
${ }^{9}$ Brewer (1996) suggests a third version based on the hypothesis that adverse effects on performance will be exerted more often by central administrators than local administrators. This is consistent with the Brennan and Buchanan (1971) hypothesis that argues that centralization of government promotes its over-expansion. Brewer (1996) finds some support for this third hypothesis that predicts that the greater the number of central administrators, the lower is overall performance.

${ }^{10}$ In a well-cited study that examines 65 studies in the input-output literature, Hanushek (1986) finds little evidence that such input ratios are linked to student performance.
} 
$H E R F_{i}=$ Herfindahl index score for student enrolment by school district; DISTRICTS $S_{i}=$ number of school districts per 1000 students; $D E N S I T Y_{i}=$ population density, population divided by square miles; $P E R F_{i}=$ verbal or math SAT scores, or dropout rates; $T A K E R_{i}=$ percentage of high school seniors taking the SAT; EDUCATION ${ }_{i}=$ median number of years of schooling.

The seemingly unrelated regression (SUR) method is used to estimate the parameters of the system of employment and performance equations by accounting for contemporaneous correlation in the errors across equations. This is a recursive model that consists of a series of endogenous variables that are considered as a group because they appear to bear a close conceptual relationship to one another. Employment and performance measures are often grouped together as indicators of public school performance by both the public and educators and therefore the SUR technique appears to be appropriate here. Relationships between these equations are indicated when the error terms of these equations are correlated and, in this case, the SUR model allows for more efficient estimates than would arise under estimation by ordinary least squares. ${ }^{11}$

Six equations are estimated since there are three types of employment (teachers, non-teachers, and administrators) and three performance measures (math SAT, verbal SAT, and drop out rates). Data for these variables are available for most of the 57 counties for 1992 and 1993, and the system of equations are estimated separately for each year. Two sparsely populated counties did not participate in many of the data collection efforts of the California Department of Education. Significance of estimated coefficients is based on two-tailed tests at the $0.01,0.05$, and 0.10 levels.

Unless otherwise indicated, raw data are provided by the California Department of Education and usually was available at the level of school districts. These data were aggregated to the county level and then compiled into a master file with data collected from other sources. Data at the county level collected from the California Statistical Abstract of 1996 are: population, area in square miles, and median numbers of years of schooling. All data are available for 1992 and 1993, except for median education, which was only available for 1990. It is appropriate to use counties as the unit of observation since school districts in California are organized and overseen by county superintendents. Therefore, while there are various numbers of school districts within each county, they all come under the same superintendent, or central administrative office. ${ }^{12}$
All counties operate under similar equalization efforts that are administered at the state level, and the data aggregation allows consideration of the variation that is measured across counties, but at the same time, intergovernmental or interschool competition is measured within each county by the Herfindahl score.

Equation 1 shows the hypothesized determinants of three measures of school employees: administrators, teachers, and non-teachers. ${ }^{13}$ Three measures are considered so as to investigate whether greater monopoly power exerts differential effects on different employee classifications. Previous discussion suggests that such a breakdown is appropriate. Anderson et al. (1991) argue that bureaucracy theory predicts that administrators prefer to hire non-teachers over teachers, and the breakdown into three types of employees allows examination of whether differential effects are displayed. Previous discussion also indicated that an inefficient allocation of employees does not necessarily require a negative relationship between administrators, or other employees, and performance. Rather, inefficiency may be present even though marginal products are positive, and reallocation from one input to another raises performance. This model allows one to determine if one or more employee classifications yields, at the margin, higher gains in performance than another classification.

The Herfindahl index score is the sum of squares of school districts' total enrolment within a school district. Borland and Howsen (1992, 1993) use Herfindahl scores to measure intergovernmental competition and find that less concentration is related to higher performance of public schools. In Equation 1 it is hypothesized that higher levels of concentration lead to greater monopoly power that enables over-expansion of employment. The Herfindahl score based on 12th grade enrolment was also measured but because it did not alter the empirical results, those estimations are not be displayed here. Numbers of school districts is expected to exert a positive effect on employment based on the assumption that greater scale economies associated with centralization of supply are significant and therefore more districts require more employees - especially administrators and non-teaching staff. Population density is anticipated to exert a positive influence on employment based on the assumption that urban areas have greater problems associated with crime and congestion, and a greater number of non-Englishspeaking students that require more employees than rural areas.

\footnotetext{
${ }^{11}$ As Pindyck and Rubinfeld (1991: 310) discuss, SUR estimation is basically a two-stage estimation procedure that results in consistent and asymptotically efficient estimates.

${ }^{12}$ Data collection at the level of school district would provide other information, but also would entail significant effort in locating reliable data on education levels and population densities for over 1000 school districts in each of two years.

${ }^{13}$ Non-teachers are a California Department of Education classification for the sum of administrators, assistant administrators, pupil services staff, and special services staff.
} 
The determinants of the three measures of performance are listed in Equation 2. These measures are the Scholastic Aptitude Test (SAT) scores on verbal and math tests and the dropout rate. As discussed above, the effects of numbers of employees on performance are ambiguous. The extreme version of the monopoly model hypothesizes a negative effect whereby higher employment lowers performance and is often expressed for the administrative component of employment. However, a weaker version of the monopoly model hypothesizes that positive effects of employment on performance also provide evidence of the monopoly model when marginal products divided by resource prices of administrators are below those of other staff. The hypothesized sign on the employee variable is therefore an empirical question to be resolved by the data.

The Herfindhal score is expected to exert a negative influence on performance based on the monopoly model that predicts that greater monopoly power allows employees to pursue their interests at the expense of higher performance. Population density is expected to exert a negative influence on performance because of the common perception that urban areas have more problems that might negatively influence performance (e.g. crime, congestion, unemployment, and poverty) than rural areas. The percentage of high school seniors taking SAT tests is expected to exert a negative influence on test scores because a higher test-taking pool means that more lower-aptitude students are included in the pool. Median education is expected to be positively related to performance based on the expectation that higher educational achievement of parents/communities positively influences academic achievement of public school students.

Table 1 displays summary statistics of the variables from the pooled sample. A few observations follow. Average employees per student ratios are 0.003 (administrators), 0.049 (teachers), and 0.007 (non-teachers). There are roughly 333 students per administrator, 20 students per teacher, and 143 students per non-teacher. SAT verbal scores exhibit an average of 419 (out of a possible 800), with a range of 456 to 364 . SAT math scores exhibit an average of 476 , with a range of 528 to 419 . Dropout rates range from $0-8 \%$, with a mean of $3.65 \%$. Herfindahl scores average 0.295 and range from 1.0-0.056.

\section{Estimation of the 1992 equation}

Table 2 displays SUR estimations of employment and performance equations for 1992. The first column displays estimation of the teachers per student equation. The Herfindahl score exerts a positive, as hypothesized, and significant influence on numbers of teachers thus providing evidence that market power results in higher use of teachers. Numbers of school districts exerts a positive, as hypothesized, and significant influence on teachers. No influence is exerted by population density. The second column displays estimation of the non-teachers per student equation. The Herfindahl score does not exert a significant influence on numbers of non-teachers, while numbers of school districts exerts a positive, as hypothesized, and significant influence on non-teachers. No influence is exerted by population density. The third column displays estimation of the administrators per student equation. The Herfindahl score exerts a positive, as expected, significant influence on numbers of administrators, and numbers of school districts exerts a positive, as hypothesized, and significant influence on administrators. Density exerts a significant negative effect on administrators - an effect opposite to expectations.

Column 4 displays estimation of the verbal SAT score equation. Teacher and non-teacher variables do not exert significant effects, but number of administrators exerts a positive effect on scores thus indicating that counties with more administrators tend to exhibit higher scores. The Herfindahl score exerts a positive (unexpected) and significant effect on verbal SAT scores. Population density exerts a negative (as expected) and significant influence on verbal scores. Percentage of seniors taking SAT tests exerts the expected negative and significant influence on verbal scores. Median education exerts the expected positive and significant influence on verbal scores.

Table 1. Summary statistics

\begin{tabular}{lcccc}
\hline Variable & Mean & Minimum & Maximum & STD.DEV \\
\hline Administrators per student & 0.003 & 0.00005 & 0.008 & 0.0011 \\
Teachers per student & 0.049 & 0.002 & 0.083 & 0.009 \\
Non-teachers per student & 0.007 & 0.001 & 0.013 & 0.001 \\
SAT verbal & 419 & 364 & 456 & 22.12 \\
SAT math & 476 & 419 & 528 & 27.90 \\
Droput rate & 3.65 & 0 & 8 & 1.60 \\
Herfindahl score & 0.295 & 0.056 & 1.00 & 0.288 \\
Districts per student & 0.001 & 0.00003 & 0.005 & 0.001 \\
Population density & 587.87 & 1.62 & 16002 & 2126.39 \\
\% seniors taking SAT test & 33.11 & 16.84 & 61.57 & 9.71 \\
Median education & 13.22 & 12.20 & 15.40 & 0.64 \\
\hline
\end{tabular}


Table 2. SUR Estimates of employment and performance equations in 1992

\begin{tabular}{|c|c|c|c|c|c|c|}
\hline & Teachers & Non-teachers & Administrators & SATV & SATM & Dropout \\
\hline \multirow[t]{2}{*}{ Constant } & $0.04^{\mathrm{a}}$ & $0.01^{\mathrm{a}}$ & $0.002^{\mathrm{a}}$ & $-1440.50^{b}$ & $-219.09^{\mathrm{a}}$ & $14.42^{\mathrm{a}}$ \\
\hline & 53.33 & 25.86 & 17.65 & 2.39 & 3.15 & 3.77 \\
\hline \multirow[t]{2}{*}{ Teachers } & & & & 874.59 & 591.30 & -5.70 \\
\hline & & & & 1.43 & 0.08 & 0.14 \\
\hline \multirow[t]{2}{*}{ Non-teachers } & & & & -3067.72 & -454.80 & $301.81^{\mathrm{c}}$ \\
\hline & & & & 1.33 & 0.17 & 1.90 \\
\hline \multirow[t]{2}{*}{ Administrators } & & & & $6431.05^{\mathrm{c}}$ & -30.19 & $-952.95^{\mathrm{a}}$ \\
\hline & & & & 1.76 & 0.01 & 2.72 \\
\hline \multirow[t]{2}{*}{ Herfindahl } & $0.01^{\mathrm{a}}$ & 0.001 & $0.001^{\mathrm{a}}$ & $17.00^{\mathrm{b}}$ & $22.48^{b}$ & -0.12 \\
\hline & 3.90 & 0.77 & 4.05 & 2.26 & 2.53 & 0.17 \\
\hline \multirow[t]{2}{*}{ Districts } & $5.14^{\mathrm{a}}$ & $0.59^{\mathrm{a}}$ & $0.64 \mathrm{a}$ & & & \\
\hline & 10.97 & 3.78 & 8.80 & & & \\
\hline \multirow[t]{2}{*}{ Density } & 7E-08 & $-5 \mathrm{E}-08$ & $-8 \mathrm{E}-08^{\mathrm{b}}$ & $-0.01^{\mathrm{a}}$ & -0.001 & $0.0002^{b}$ \\
\hline & 0.27 & 0.63 & 2.13 & 4.60 & 1.12 & 2.19 \\
\hline \multirow[t]{2}{*}{ Takers } & & & & $-1.62^{\mathrm{a}}$ & $-2.22^{\mathrm{a}}$ & \\
\hline & & & & 4.52 & 5.26 & \\
\hline \multirow[t]{2}{*}{ Median education } & & & & $43.32^{\mathrm{a}}$ & $55.91^{\mathrm{a}}$ & $-0.75^{\mathrm{a}}$ \\
\hline & & & & 9.34 & 10.18 & 2.62 \\
\hline Adj. $R^{2}$ & 0.72 & 0.20 & 0.66 & 0.60 & 0.64 & 0.32 \\
\hline s.e.e. & 0.0039 & 0.001 & 0.001 & 14.22 & 16.73 & 1.34 \\
\hline$n$ & 57 & 57 & 57 & 57 & 57 & 57 \\
\hline
\end{tabular}

Notes: ${ }^{\mathrm{a}, \mathrm{b}, \mathrm{c}}$ refer to significance at $0.01,0.05$, and 0.10 levels.

Column 5 displays estimation of the math SAT score equation. No employment category exerts a significant effect on scores. The Herfindahl score exerts a positive (unexpected) and significant effect on math SAT scores. Percentage of seniors taking SAT tests exerts the expected negative and significant influence on verbal scores. Median education exerts the expected positive and significant influence on verbal scores.

Column 6 displays estimation of the dropout equation. While teachers do not exert a significant effect on dropout rates, non-teachers (positive) and administrators (negative) exert signficant effects. That is, higher numbers of nonteachers appear to raise dropout rates, while higher numbers of administrators lower dropout rates. Population density exerts a positive and significant effect on dropout rates, and median education exerts a negative, as hypothesized, and significant effect on dropout rates.

\section{Estimation of the 1993 equation}

Table 3 displays SUR estimations of employment and performance equations for 1993. The first column displays estimation of the teachers-student equation. The Herfindahl score exerts a positive, as hypothesized, and significant influence on numbers of teachers thus providing evidence that market power results in higher use of teachers. Numbers of school districts exerts a positive, as hypothesized, and significant influence on teachers. No influence is exerted by population density. The second column displays estimation of the non-teachers per student equation. The Herfindahl score does not exert a significant influence on numbers of non-teachers, while numbers of school districts exerts a positive, as hypothesized, and significant influence on non-teachers. No influence is exerted by population density. The third column displays estimation of the administrators-student equation. The Herfindahl score exerts a positive, as expected, significant influence on numbers of administrators, and numbers of school districts exerts a positive, as hypothesized, and significant influence on administrators. Density exerts a significant negative effect on administrators - an effect opposite to expectations. With the exception of density exerting a significant effect on numbers of administrators (versus no effect in 1992), the results of the first three columns mirror those found in 1992.

Column 4 displays estimation of the verbal SAT score equation. Teachers do not exert significant effects (as in 1992), but numbers of non-teachers exert a negative effect on verbal scores (versus no effect in 1992). As in 1992, numbers of administrators exert a positive effect on verbal scores. Unlike the positive and significant effect in 1992, the Herfindahl score does not exert a significant effect on verbal SAT scores. As in 1992, population density exerts a negative and significant influence, the percentage of seniors taking SAT tests exerts negative and significant influence, and median education exerts the expected positive and significant influence on verbal scores.

Column 5 displays estimation of the math SAT score equation. No employment category exerts a significant effect on math scores - thus mirroring results in 1992. Contrary to 1992, the Herfindahl score no longer exerts a positive and significant effect on math SAT scores. Density 
Table 3. SUR Estimates of employment and performance equations in 1993

\begin{tabular}{|c|c|c|c|c|c|c|}
\hline & Teachers & Non-teachers & Administrators & SATV & SATM & Dropout \\
\hline \multirow[t]{2}{*}{ Constant } & $0.04^{\mathrm{a}}$ & $0.01^{\mathrm{a}}$ & $0.002^{\mathrm{a}}$ & $-116.43^{b}$ & $-121.25^{\mathrm{b}}$ & $14.85^{\mathrm{b}}$ \\
\hline & 24.16 & 18.12 & 10.39 & 2.26 & 2.23 & 3.39 \\
\hline \multirow[t]{2}{*}{ Teachers } & & & & 411.00 & -349.10 & 19.33 \\
\hline & & & & 1.04 & 0.84 & 0.56 \\
\hline \multirow[t]{2}{*}{ Non-teachers } & & & & $-3982.94^{c}$ & 1969.85 & 153.32 \\
\hline & & & & 1.81 & 0.85 & 0.89 \\
\hline \multirow[t]{2}{*}{ Administrators } & & & & $11866.06^{\mathrm{a}}$ & -5.395 .09 & $-995.93^{a}$ \\
\hline & & & & 3.57 & 1.53 & 3.26 \\
\hline \multirow[t]{2}{*}{ Herfindahl } & $0.01^{\mathrm{b}}$ & 0.001 & $0.001^{\mathrm{a}}$ & 1.78 & -2.60 & -0.63 \\
\hline & 2.48 & 0.73 & 3.32 & 0.23 & 0.32 & 0.76 \\
\hline \multirow[t]{2}{*}{ Districts } & $5.31^{\mathrm{a}}$ & $0.51^{\mathrm{a}}$ & $0.59^{\mathrm{a}}$ & & & \\
\hline & 6.42 & 2.77 & 6.06 & & & \\
\hline \multirow[t]{2}{*}{ Density } & 9E-07 & $-3 \mathrm{E}-07$ & $-7 \mathrm{E}-08$ & $-0.01^{b}$ & $0.01^{\mathrm{c}}$ & 0.0002 \\
\hline & 0.62 & 0.92 & 0.35 & 2.03 & 1.80 & 0.81 \\
\hline \multirow[t]{2}{*}{ Takers } & & & & $-1.40^{\mathrm{a}}$ & $-1.51^{\mathrm{a}}$ & \\
\hline & & & & 5.51 & 5.65 & \\
\hline \multirow[t]{2}{*}{ Median education } & & & & $42.40^{\mathrm{a}}$ & $47.80^{\mathrm{a}}$ & $-0.78^{a}$ \\
\hline & & & & 10.39 & 11.13 & 2.43 \\
\hline Adj. $R^{2}$ & 0.48 & 0.15 & 0.52 & 0.60 & 0.75 & 0.28 \\
\hline s.e.e. & 0.007 & 0.001 & 0.001 & 13.70 & 14.05 & 1.44 \\
\hline$n$ & 53 & 53 & 53 & 53 & 53 & 53 \\
\hline
\end{tabular}

Notes: ${ }^{\text {a,b,c }}$ refer to significance at $0.01,0.05$, and 0.10 levels.

exerts a positive and significant effect, versus no effect in 1992. As in 1992, percentage of seniors taking SAT tests (negative) and median education (positive) exert significant influences on verbal scores.

Column 6 displays estimation of the dropout equation. As in 1992, teachers do not exert a significant effect. But, while non-teachers exerted a positive, but weakly significant, effect in 1992, it no longer exerts a significant effect. However, as in 1992, numbers of administrators exert a negative and significant effect on dropout rates. Unlike its positive and significant effect in 1992, population density does not significantly influence dropout rates. Finally, median education continues to exert a negative and significant effect on dropout rates.

\section{CONCLUSIONS}

The hypothesis that monopoly power of school districts allows bureaucratic expansion and poor academic performance has been tested in the public school system of California. Evidence indicates that monopoly power is positively associated with employment of administrators and teachers, thus supporting the bureaucratic expansion hypothesis. No support is found for the case of nonteachers.

The hypotheses that higher employment of teachers and administrators exert negative effects on performance, as measured by SAT scores and dropout rates, are not sup- ported. Variation in numbers of teachers does not explain any variation in performance measures. However, higher employment of administrators is found to raise verbal SAT scores and lower drop out rates. Higher numbers of nonteachers are also found to lower verbal SAT scores (in 1993) and raise drop out rates (in 1992), thus providing some evidence that this employment group exerts negative effects on performance. The evidence appears to suggest that California public schools hire too few administrators and too many non-teachers, based on the prediction that greater numbers of administrators and fewer non-teachers would raise verbal SAT scores and lower drop out rates. The evidence also indicates that performance differences are unrelated to variation in numbers of teachers - thus suggesting that the public push towards smaller class sizes may not raise student achievement.

While misallocation of staffing resources may suggest bureaucratic over-expansion, this result simply indicates that staff resources are misallocated in the California public school system. Bureaucracy theory is one model that explains resource misallocation, but others reasons may also explain why too many non-teachers and too few administrators appear to be hired. As just mentioned, rising public pressures that place hiring priorities on teachers may crowd-out non-teachers and administrators. Equalization policies may also contribute to resource misallocation when funding decisions focus on spending equality, which is not necessarily related to performance equality across schools and school districts. Public pres- 
sures on hiring more teachers and spending equalization policies may therefore influence resource allocation and, because they do not emanate from competitive private market pressures, they do not necessarily reflect efficiency-enhancing reallocations of school resources. The weak California economy in 1992-1993 may also have played a role in misallocation that may be resolved over time.

From a public policy viewpoint, this paper suggests that a focus - either by the public or policymakers - on teacherstudent ratios is not necessarily the most productive means of fostering higher performance in our public school systems. As previously discussed, efficient resource allocation does not necessarily result in uniform teacher-student ratios across schools since marginal products, input prices, and budgets vary across schools. Public pressures and/or policymakers that force uniformity may contribute to lower overall performance when 'magic' formulae for teacher-student ratios are promoted. It should also be noted that variation of staffing across schools does not necessarily indicate bureaucratic over-expansion since variation may simply be a product of schools trying to adopt their uniquely efficient hiring ratios, or a product of public pressures to hire more teachers, equalization policies, or a weak economy. Moreover, it is difficult to know what constitutes efficient staffing decisions when private market counterparts that must endure the competitive pressures of the marketplace are fairly weak or absent. When employment is related to monopoly power, Niskanen's theory of bureaucracy predicts that public school staff operate at relatively high levels of autonomy from sponsors due to substantial monitoring costs and lack of private market counterparts with which to make comparisons of such items as costs and performance. Sponsors are therefore likely to find oversight a relatively difficult endeavour and it should not be surprising that arguments for higher funding are difficult to assess since they may be selfinterested attempts to over-expand or genuine attempts to improve educational performance in least-cost manners. However, given high monitoring costs and lack of comparative information in private markets, sponsor-focus on teacher-student ratios may be rational since it is a fairly easy statistic to view and compare across other public schools. Unfortunately, this paper provides evidence that even if rational for sponsors, reallocations towards other inputs such as administrators and away from teachers and non-teachers may offer more promise for performance gains.

\section{ACKNOWLEDGEMENTS}

I would like to thank Alden F. Shiers and an anonymous referee for helpful comments.

\section{REFERENCES}

Anderson, G. M., Shughart II W. F. and Tollison, R. D. (1991) Educational achievement and the cost of bureaucracy, Journal of Economic Behavior and Organization, 15, 29-45.

Borland, M. and Howsen, R. (1993) On the determination of the critical level of market concentration in education, Economics of Education Review, 12, 165-9.

Borland, M. and Howsen, R. (1992) Student academic achievement and the degree of market concentration in education, Economics of Education Review, 11, 1-39.

Brennan, G. and Buchanan, J. M. (1980) The Power to Tax: Analytical Foundations of a Fiscal Constitution, Cambridge University Press, Cambridge.

Brewer, D. J. (1996) Does more school administration lower educational productivity? some evidence on the 'administrative blob' in New York public schools, Economics of Education Review, 15, 111-24.

Couch, J. F., Shughart II, W. F. and Williams, A. L. (1993) Private school enrollment and public school performance, Public Choice, 76, 301-12.

Downes, T. A. (1996) An examination of the structure of governance in California school districts before and after proposition 13, Public Choice, 86, 279-307.

Education Data Partnership (1998) California's rankings, 199495, ED FACT Sheet, February.

Fischel, W. A. (1988) Did Serrano cause proposition 13?, National Tax Journal, 42, 465-73.

General Accounting Office (1997) State Efforts to Reduce Funding Gaps Between Poor and Wealthy Districts, US Government.

Hamilton, B. W. and Macauely, M. K. (1991) Determinants and consequences of the private-public school choice, Journal of Urban Economics, 29, 282-94.

Hanushek, E. A. (1986) The economics of schooling. production and efficiency in public schools, Journal of Economic Literature, 24, 1141-77.

Hirschman, A. O. (1970) Exit, Voice and Loyalty, Harvard University Press, Cambridge.

Marlow, M. L. (1992) Intergovernmental competition voice and exit options and the design of fiscal structure, Constitutional Political Economy, 3, 73-87.

Marlow, M. L. (1997) Public education supply and student performance, Applied Economics, 29, 617-26.

Martinez-Vazquez, J. and Seaman, B. (1985) Private schooling and the Tiebout hypothesis, Public Finance Quarterly, 13, 293-318.

Newmark, C. M. (1995) Another look at whether private schools influence public school quality: comment, Public Choice, 82, $365-73$.

Niskanen, W. A., Jr. (1971) Bureaucracy and Representative Government, Aldine-Atherton, Chicago.

Pindyck, R. S. and Rubinfeld, D. L. (1991) Econometric Models \& Forecasts, 3rd edn, McGraw-Hill, New York.

Silva, F. and Sonstelie, J. (1995) Did Serrano cause a decline in school spending?, National Tax Journal, 48, 199-208.

Sonstelie, J. (1979) Public school quality and private school enrollments, National Tax Journal, 32, 343-53.

Tiebout, C. M. (1956) A pure theory of local expenditures, Journal of Political Economy, 64, 416-24.

West, E. G. (1990) Public education via exclusive territories, Public Finance Quarterly, 18, 371-94.

West, E. G. and Halldor Palsson (1988) Parental choice of school characteristics: estimation using state-wide data, Economic Inquiry, XXVI, 725-40. 